\title{
Investigation of the Genotoxic, Cytotoxic, Apoptotic, and Oxidant Effects of Olive Leaf Extracts on Liver Cancer Cell Lines
}

\section{Zeytin Yaprağı Ekstrelerinin Karaciğer Kanseri Hücre Hatları Üzerine Genotoksik, Sitotoksik, Apoptotik ve Oksidan Etkilerinin Araştırılması}

\author{
(D) Muhammed Yunus BEKTAY1*, (D) Eray Metin GÜLER², (D) Mustafa GÖKÇE3, (D) Mustafa Volkan KIZILTAŞ4 \\ ${ }^{1}$ Bezmialem Vakıf University Faculty of Pharmacy, Department of Clinical Pharmacy; Marmara University Institute of Health Sciences, Department of \\ Clinical Pharmacy, İstanbul, Turkey \\ 2University of Health Sciences, Hamidiye Faculty of Medicine, Department of Medical Biochemistry; Haydarpaşa Numune Health Application and Research \\ Center, Department of Medical Biochemistry, İstanbul, Turkey \\ 3Bezmialem Vakıf University Faculty of Pharmacy, Department of Parhmacology, İstanbul, Turkey \\ 4istanbul University Faculty of Pharmacy, Department of Analytical Chemistry, İstanbul, Turkey
}

\begin{abstract}
Objectives: Hepatocellular carcinoma ( $\mathrm{HCC}$ ) is the seventh most common cancer and the third leading cause of tumor-related deaths worldwide. Mechanisms underlying tumor onset, progression, and metastasis in the case of HCC have not been adequately studied. In this study, we aimed to investigate the genotoxic, cytotoxic, apoptotic and oxidant effects of olive leaf extract (OLE) on HCC cells.

Materials and Methods: H4IIE Rattus norvegicus hepatoma cells and Rattus norvegicus healthy liver clone-9 cells were treated with the increasing concentrations of OLEs (250-2000 ppm) in ethanol, acetone, dichloromethane, and methanol. ATP cell viability, intracellular reactive oxygen species generation levels, double staining test with acridine orange/ethidium bromide, comet assay, levels of interleukin 1-beta (IL-1 $\beta$ ), IL-6, and tumor necrosis factor alpha were measured. Significance was determined using ANOVA test.

Results: Apoptotic, genotoxic, cytotoxic, and oxidative effects of OLEs increased with the increasing concentrations as compared to controls in H4IIE cells ( $p<0.001$ ).

Conclusion: This is the first study to show a significant and selective cytotoxic activity of OLEs in the selected H4llE cancer cell lines. OLEs could selectively increase the apoptotic damage and show anti-proliferative and pro-apoptotic properties against the H4lIE cells. They could be recommended as potential nutraceuticals in the prevention of cancer.
\end{abstract}

Key words: Olive leaf, hepatocellular carcinoma, oleuropein, oxidative stress, genotoxicity, apoptosis

öz

Amaç: Hepatoselüler karsinoma (HSK), en yaygın yedinci kanser türüdür ve kanserle ilișkili ölümlerde üçüncü sırada yer almaktadır. HSK'de tümör başlangıcına, ilerlemesine ve metastazlara neden olan mekanizmalar tam olarak bilinmemektedir. Bu çalışmada zeytin yaprağı ekstresinin (OLE) HSK hücreleri üzerine genotoksik, sitotoksik, apoptotik ve oksidan etkilerinin araştırılması amaçlanmıştır.

Gereç ve Yöntemler: H4lIE Rattus norvegicus hepatoma hücrelerine ve Rattus norvegicus sağlıklı karaciğer klon-9 hücrelerine etanol, aseton, diklorometan ve metanol içinde artan konsantrasyonlarda OLE'leri (250-2000 ppm) uygulanmıştır. Ekstrelerin sitotoksisitesi ATP testiyle, hücre içi reaktif oksijen türlerinin oluşumu florometrik yöntemlerle, genotoksik etkileri alkalen tekli hücre jel elektroforez (comet assay) yöntemiyle, apoptotik etkileri akridin turuncusu/etidyum bromür yöntemiyle ölçülmüștür. İnterlökin 1 beta ( IL-1 $\beta$ ), IL-6 ve tümör nekroz faktörü alfa düzeyleri ELISA yöntemi ile belirlenmiştir. İstatistiksel test olarak ANOVA testi kullanılmıştır.

Bulgular: OLE'nin apoptotik, genotoksik, sitotoksik ve oksidatif etkileri H4IIE hücrelerinde kontrole göre artan konsantrasyonlarla istatistiksel olarak anlamlı şekilde yükselmiştir ( $p<0,001$ ).

*Correspondence: yunusbektay@gmail.com, Phone: +90 212523 22 88, ORCID-ID: orcid.org/0000-0003-2032-9957

Received: 02.12.2020, Accepted: 26.03.2021

๑Turk J Pharm Sci, Published by Galenos Publishing House. 
Sonuç: Bu çalışma, H4IIE kanser hücre hatlarında OLE'nin seçici sitotoksik aktivitesini gösteren ilk çalışmadır. OLE apoptozu indüklemiş ve H4lIE hücrelerine karşı anti-proliferatif ve pro-apoptotik özellikler göstermiștir. Kanserin önlenmesinde potansiyel nutrasötikler olarak önerilebilirler. Anahtar kelimeler: Zeytin yaprağı, hepatosellüler kanser, oleuropein, oksidatif stres, genotoksite, apopitoz

\section{INTRODUCTION}

Hepatocellular carcinoma (HCC) is the seventh most common cancer and the third leading cause of cancer-related mortality worldwide. Despite significant advances in the diagnosis and treatment, HCC remains a terminal disease. The most common cause for mortality in HCC is progression and the metastasis. However, the molecular mechanisms underlying tumor onset, progression, and metastasis in the case of HCC have not been adequately studied.' The neoplastic development of HCC is related to many histological incidents. Hyperplastic nodules formed in the hepatocyte regeneration observed in the liver in response to the cell deaths due to risk factors are cytologically of normal findings, which will be the first step in HCC formation. These lesions may transform into premalignant dysplastic nodules and cause nuclear aggregation with cytologically welldetected cell changes. As a result of molecular analysis in the HCCs, various genetic and epigenetic changes have been detected.

Epidemiological studies and animal experiments have been revealed that some nutritional compounds play a role in the incidence rates of various cancers, including HCC. Onethird of all the known human cancers may be related to specific components of nutrients. ${ }^{1-3}$ Many research groups are investigating the effects of nutritional components on cancer processes and state that dietary fats increase the risk of brain, colon, breast, and prostate cancer. In addition, the incidence of the brain, cardiovascular diseases, and colon and breast cancers are lower in the Mediterranean Region than in Europe. 4,5 Around the Mediterranean and European territories olive tree leaf (Olea europaea L.) is commonly used as traditional medicine. Olive leaf extract (OLE) has been reported to show anti-aging, immune system enhancing, and antimicrobial effects. ${ }^{6}$ In studies, olive leaf antioxidants have been shown to be effective in the treatment of cancers like liver, prostate, and breast.,8 Olive leaf contains substantial secoiridoids, flavonoids, phenolic acids, and the lignans. Of these, oleuropein is an important phenolic compound in the secoiridoid group. ${ }^{7}$ Oleuropein and its metabolite hydroxytrizole (HT) have antioxidant activity, showed in both in vivo and in vitro experimental models. ${ }^{6,7}$ In addition to in vivo and in vitro activities, the antioxidant potential of oleuropein and HT has also been investigated on experimental cell line models and animal models. ${ }^{6-8}$ In recent epidemiological studies, it was shown that OLEs rich in phenolic compounds correlated with a decreased cardiovascular risk, neurodegenerative disease, and cancer. ${ }^{6-9}$ Besides the different phenolics and flavonoids olive leaves contain the most oleuropein content when compared with other parts of the plan such as root, bark, fruit. ${ }^{9}$ In this study, it was aimed to investigate the in vitro genotoxic, cytotoxic, apoptotic, and oxidant effects of OLE on the HCC cell lines.

\section{MATERIALS AND METHODS}

\section{Collection of plant samples}

The plants have been purchased commercially as medical drugs with a batch number of 26/0/2019. Plant leaves of Olea europaea L. were dried at room temperature, then shredded with a plant shredder and stored at room temperature until they were used in the study.

Preparation of methanol, acetone, dichloromethane, and aqueous-ethanol extracts

The preparation of OLEs was performed for the methanol extract $(\mathrm{O}-\mathrm{MeOH})$, acetone (O-ACE), dichloromethane (O-DCM), and aqueous-ethanol extract $(\mathrm{O}-\mathrm{EtOH})$, a total of $70 \mathrm{~g}$ of the plant sample was ground with a laboratory blender, extracted in the solvent, and after the extraction, the extract has been filtered, followed by the evaporation of the solvent. The amount of oleuropein was expressed as milligram per gram of OLE. The OLE was dissolved in dimethyl sulfoxide (0.1\%) prior to the analysis.

\section{Determination of total phenolic and flavonoid content}

The total amount of phenolic compounds found in the extracts was determined with the Folin-Ciocalteu Reagent. ${ }^{10}$ Gallic acid (GA) was used as a standard phenolic compound. The total amount of phenolic compounds found in all OLEs was evaluated according to the study conducted by Gülçin et al.11 The findings were given in GA equivalent (GAE) and micrograms.

The total amount of flavonoids found in all the OLEs was determined by the method of Park et al. ${ }^{12}$ Quercetin was used as the standard. Total flavonoid concentration was calculated as quercetin equivalent.

\section{Determination of free radical activity}

The free radical scavenging activities of the extracts were determined using the 1,1-Diphenyl-2-picrylhydrazyl (DPPH) free radical. ${ }^{13}$ The absorbance was measured at $517 \mathrm{~nm}$, values of the samples were evaluated against the control. As standard, butylated hydroxy anisole (BHA), BH toluene (BHT), and $\alpha$-tocopherol ( $\alpha$-Toc) were used.

\section{Determination of ABTS cation radical scavenging activity}

This method was used to assess the potential of the extracts to sweep the ABTS cation radical. The absorbance of each solution was detected at $734 \mathrm{~nm}$, and the inhibition \% was calculated..$^{14}$

\section{Determination of reduction force}

The cupric ion $\left(\mathrm{Cu}^{2+}\right)$ reduction capacities of the extracts were measured with the CUPRAC method. ${ }^{15}$ As standard, BHA, BHT, and $\alpha$-Toc were used. 


\section{High-performance liquid chromatography (HPLC) analysis}

The amount of oleuropein in leaf extracts was measured by HPLC according to the method developed by Al-Rimawi. ${ }^{16}$ HPLC analysis was performed using the Shimadzu (Japan) LC-20A model, and the peak areas of automatic injections of $20 \mu \mathrm{L}$ with ultraviolet (UV) detector were calculated using the LC solution computer software. Chromatographic separation was attempted to be optimized using $C_{18}(5 \mu \mathrm{m}, 150 \times 4.6 \mathrm{~mm})$ and $C_{8}$ (5 $\mathrm{mm}, 150 \times 4.6 \mathrm{~mm}$ ) columns.

The calibration coefficient was calculated from the calibration curve created by the concentration-dependent linear mathematical equation of the field data, and linearity was calculated (Figure 1G). The UV detection of the separation was performed using the mobile phase of the water $(\mathrm{pH}: 3)$ :

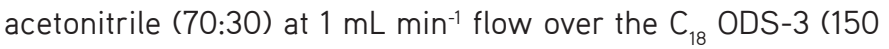
$\mathrm{mm}, 4.6 \times 5 \mathrm{~mm}$ ) column at $280 \mathrm{~nm}$. The linear coefficient of the linear calibration curve created in the range of $100-1000 \mu \mathrm{g} / \mathrm{mL}$ was found to be 0.99 .

\section{Cell culture}

H4lIE [American Cell Cultures Collection (ATCC) ${ }^{\circledR}$ CRL$1548^{\mathrm{TM}}$ ] Rattus norvegicus hepatoma cells were obtained from the (ATCC, Middlesex, UK). Cells were grown in the Eagle's minimum essential medium containing $10 \% \mathrm{FBS}$ and $1 \% \mathrm{P} / \mathrm{S}$ in a humidified incubator with $5 \% \mathrm{CO}_{2}$ at $37^{\circ} \mathrm{C}$.

Healthy rat liver cell clone-9 cells (ATCC ${ }^{\circledR}$ CRL-1439 ${ }^{\text {TM }}$ ) were obtained from ATCC (Middlesex, UK). Cells were grown in an F12K medium containing $10 \%$ FBS, and $1 \% \mathrm{P} / \mathrm{S}$ in a humidified incubator with $5 \% \mathrm{CO}_{2}$ at $37^{\circ} \mathrm{C}$. Samples were prepared at different doses and left for 24-hour incubation in cells. Each dose was analyzed with a minimum of four replicates.

\section{Cytotoxicity assay}

To measure cytotoxicity in cancer and healthy cells, $1.5 \times 10^{4}$ cells per well were added to 96 opaque white plates. Samples of different concentrations were added and incubated for 24 hours. After incubation, the ATP solution was added to the wells and measured luminometrically using the Cell Titer-Glo ${ }^{\circledR}$ Luminescent Cell Viability Test Kit.

\section{Intracellular reactive oxygen generation}

The intracellular reactive oxygen species (ROS) levels were measured using the $\mathrm{H}_{2}$ DCF fluorescence probe. Cancer and healthy cells seeded on the opaque black plates, and samples of different concentrations (250-2000 ppm) were incubated for 24 hours. After the incubation, cells were washed three times with dPBS and incubated at $37^{\circ} \mathrm{C}$ in the dark with $5 \mu \mathrm{M} \mathrm{H}_{2} \mathrm{DCFH}-\mathrm{DA}$. After the cells were washed, fluorometric measurements were taken at Ex: $482 \mathrm{~nm} / \mathrm{Em}$ : $512 \mathrm{~nm}$. Results were normalized according to the ATP levels.

\section{Apoptosis}

Acridine orange $(A O)$ /ethidium bromide $(E B)$ dye was used to measure the apoptosis. ${ }^{17}$ After mixing $A O / E B$ and cell pellet in a 1:1 ratio, images were taken under a fluorescence microscope (Leica DM 1000, Solms, Germany). The separation of apoptotic cells performed according to the morphological characteristics of the nuclei. Apoptotic cell nuclei take up only EB. On the other hand, $\mathrm{AO}$ is taken up by both living and dead cells. Green fluorescence at $480-490 \mathrm{~nm}$ was flared by living cells. Healthy cells flared green fluorescence while apoptotic cells luminating yellow-orange and necrotic cells were seen red. Briefly, $2 \times 10^{5}$ H4IIE and clone-9 cells/well were seeded in 6-well plates and incubated for 24 hours. Cells seeded in 6-well plates under $\mathrm{IC}_{50}$ doses were washed for 24 hours after incubation with the samples. The preferred solution for collection of the cells and washing was PBSR, then cells were stained with 1:1 mixture of AO/EB $(100 \mu \mathrm{g} / \mathrm{mL})$. Triplicate samples of 100 cells each were counted and scored for the incidence of apoptotic chromatin condensation using a fluorescent microscope (Leica DM 1000, Solms, Germany). ${ }^{17,18}$ Apoptotic cells were calculated relative to the total number of cells. ${ }^{18}$

\section{Genotoxicity}

Genotoxicity analysis was performed according to the comet assay method in our previous study. DNA damage in cells was given as tail intensity percentage. ${ }^{19}$ Comet assay (alkaline single cell gel electrophoresis assay) with a slight modification of Singh et al.'s ${ }^{19}$ methods was carried out to assess the genotoxic effects of OLEs on H4IIE and clone-9 cells. The 6-well cell culture containing the cell culture medium plates were used. For the evaluation of genotoxicity approximately $2 \times 10^{5}$ cells per well plated on wells at $37^{\circ} \mathrm{C}$. Then, the OLE samples $<\mathrm{IC}_{50}$ concentrations were added and incubated for 24 hours. Trypsin-EDTA (0.25\%) used for collection of the cells and, phenol red for 2-3 $\mathrm{min}$ in the incubator. The cells were centrifuged at $1500 \mathrm{x} \mathrm{rpm}$ for $5 \mathrm{~min}$ at $4^{\circ} \mathrm{C}$. The supernatant was withdrawn, and the cell density of $2 \times 10^{5}$ cells $/ \mathrm{mL}$ was adjusted with cold dPBS. Total of $15 \mu \mathrm{L}$ cell suspension and 85 $\mu \mathrm{L}$ of $0.6 \%$ low melting point agarose were mixed and placed on $1 \%$ normal melting point agarose precoated slides. The gel mixture was solidified on a cold tray for 2 mins, and the slides were treated for overnight with lysis buffer, $\mathrm{pH} 10.0$ (1\% Triton X-100, 2.5 M NaCl, 10 mM Tris, 0.1 M EDTA, Sigma-Aldrich). In an alkaline solution, the incubation of the slides performed $(0.3$ $\mathrm{M} \mathrm{NaOH}, 1 \mathrm{mM}$ EDTA, Sigma-Aldrich) for $40 \mathrm{~min}$ in the dark in the presence of cooling blocks to unwind the DNA. At $0.72 \mathrm{~V} /$ $\mathrm{cm}\left(26 \mathrm{~V}, 300 \mathrm{~mA}\right.$ ) for $25 \mathrm{~min}$ in an electrophoresis tank at $4^{\circ} \mathrm{C}$, $0.72 \mathrm{~V} / \mathrm{cm}(26 \mathrm{~V}, 300 \mathrm{~mA}$ ) electrophoresis was performed for $25 \mathrm{~min}$. The slide was again treated with tris buffer $(0.4 \mathrm{M}$ Tris, $\mathrm{pH}: 7.5)$ for 5 mins. Before staining the slides, ethanol was used for dehydrating the slides. A staining procedure with EB $(2 \mu \mathrm{g} /$ $\mathrm{mL}$ in distilled $\mathrm{H}_{2} \mathrm{O}, 70 \mu \mathrm{L} /$ slide) applied to the slides and coated with a coverslip and scored under fluorescence microscope (Leica DM 1000, Solms, Germany) using the Comet assay IV software (Perceptive Instruments, Suffolk, UK).

\section{Inflammation assays}

Cancer and healthy cells were incubated at concentrations $\left\langle I C_{50}\right.$ for 24 hours. The levels of interleukin-1 $1 \beta$ (IL-1 $1 \beta), I L-6$, and tumor necrosis factor $\alpha$ (TNF- $\alpha$ ) in the medium were measured by commercially available ELISA kits (Elabscience, Texas, USA) by photometric methods. Levels of IL-1 $\beta, I L-6$, and TNF- $\alpha$ in a cell medium after 24-hour incubation were measured by the ELISA 
method according to the protocol provided by the manufacturer. All ELISA kits were purchased from Elabscience (Texas, USA). IL1 $\beta$, IL6, and TNF- $\alpha$ levels were read at $450 \mathrm{~nm}$ using an ELISA plate reader (Thermo Scientific, Massachusetts- USA), and the concentrations were calculated according to the standard curves obtained from the external standards.

\section{Statistical analysis}

All experiments were repeated for the minimum number of 4 times. Results are given as mean \pm standard deviation. Variance analysis was done with One-Way ANOVA. p<0.05 level was considered as statistically significant. Regression analysis was done for $I_{50}$ values. All analyzes were done with the Statistical Package Program for Social Sciences (IBM, Inc version 25).

\section{RESULTS}

Flavonoid and phenol content, free radical activity, ABTS cation radical scavenging activity, reduction force, and oleuropein level analysis

Polyphenolic compounds, namely flavonoids, phenolic acids, and their derivatives, are typical phytochemicals for olive leaves. Total flavonoid levels in O-DCM, O-ACE, O-MeOH, and $\mathrm{O}-\mathrm{EtOH}$ were found 8.52, 7.18, 3.29, and $1.73 \mathrm{mg} \mathrm{QUE} / \mathrm{mL}$, respectively (Figure $1 \mathrm{~A}$ ), while total phenolic levels in $0-D C M$, $\mathrm{O}-\mathrm{ACE}, \mathrm{O}-\mathrm{MeOH}$, and $\mathrm{O}-\mathrm{EtOH}$ were 11.24, 6.92, 9.96, and 9.81 $\mathrm{mg} \mathrm{GAE} / \mathrm{mL}$, respectively (Figure $1 \mathrm{~B}$ ).

The free radical scavenging activities of the extracts are determined using the DPPH free radical (Figure 1C). O-DCM showed inhibitions of $0.13 \%, 0.13 \%, 18.72 \%$, and $18.85 \%$ with different concentrations. O-ACE showed inhibitions of $9.49 \%$, $18.72 \%, 41.54 \%$, and $81.85 \%$ with different concentrations. $\mathrm{O}-\mathrm{MeOH}$ showed inhibitions of $6.63 \%, 19.76 \%, 42.78 \%$, and $81.85 \%$ with different concentrations. BHA was used as a standard.

ABTS cation radical scavenging activity of the extracts was showed in Figure 1D. O-DCM showed inhibitions of $9.96 \%$, $0.13 \%, 18.72 \%$, and $18.85 \%$ with different concentrations. O-ACE showed inhibitions of $30.32 \%, 65.82 \%, 70.54 \%$, and $87.14 \%$ with different concentrations. $\mathrm{O}-\mathrm{MeOH}$ showed inhibitions of $18.13 \%$, $50.43 \%, 85.49 \%$, and $85.93 \%$ with different concentrations. $\mathrm{O}-\mathrm{EtOH}$ showed inhibitions of $42.30 \%, 69.89 \%, 87.36 \%$, and $86.92 \%$ with different concentrations. The determination of reducing ability was showed as absorbance levels of extracts (Figure 1E). O-DCM showed absorbance of $0.14,0.24,0.31$, and 0.52 with different concentrations. O-ACE showed absorbance of $0.20,0.43,0.70$, and 1.24 with different concentrations. $\mathrm{O}-\mathrm{MeOH}$ showed absorbance of $0.17,0.39,0.60$, and 1.04 with different concentrations. BHA is used as a standard. Oleuropein level determination was conducted with HPLC as three parallels (Figure 1E). Mean values of these three were $19.56 \mathrm{mg} / \mathrm{mL}$ (O-DCM), $97.97 \mathrm{mg} / \mathrm{mL}$ (O-ACE), and $72.20 \mathrm{mg} / \mathrm{mL}(\mathrm{O}-\mathrm{MeOH})$.

\section{Inhibition of cell viability}

Cytotoxicity results of OLEs to liver hepatoma (H4IIE) and healthy liver clone-9 cells are presented in Figure 2A. These results showed a robust concentration dependent response relationship with cytotoxicity of OLEs. In Figure 2A, a gradual decrease was seen in the viability of H4IIE cells, a statistically significant difference obtained p<0.001 with increased concentrations.

\section{Intracellular iROS generation levels}

The results of the iROS of OLEs to liver carcinoma (H4IIE) and healthy liver clone-9 cells are presented in Figure 2B. There is a gradual increase in the iROS level of H4IIE cells, with all concentrations of $\mathrm{O}-\mathrm{MeOH}$ and $\mathrm{O}-\mathrm{EtOH}$ of $250,500,1000$, and 2000 ppm showed increased iROS compared to control cells ( $p<0.001)$ (Figure 2B).

\section{Induction of apoptosis}

OLEs induce Apoptosis of H4llE cells in a concentrationdependent manner, showing a gradual increase of EB-positive cells in OLEs-treated cells compared to the control, and a statistically significant difference was obtained $p<0.001$ (Figure 2C, D).

\section{Induction of DNA damage}

Extracts at all concentrations lead to the breaking of DNA singlestrand in H4llE cells, and there is a gradual concentrationresponse relationship and a statistically significant difference of $p<0.001$. Comet assay images of control and OLEs-treated H4IIE cells are presented in Figures $3 \mathrm{~A}, \mathrm{~B}$.

Anti-inflammatory activity of OLEs and its phenolic compounds Results showed that all extracts at the concentrations of 250 , 500,1000 , and 2000 ppm causes elevated levels of IL-1 $\beta$, IL-6, and TNF- $\alpha$ in H4IIE and clone-9 cells (Figure 4A-C). The OLEs had a significant activity on IL-1 $\beta, \mathrm{IL}-6$, and TNF- $\alpha$ production in a concentration-dependent manner.

\section{DISCUSSION}

Studies on Olea europaea L. generally includes data on the chemical and physical properties of the oil extracted from the fruits and their samples. There are few studies on the antioxidant activities of leaf extracts in the literature since the oil of the fruits is very valuable. Ethanol and acetone have been found to be highly effective solvents in extracting the phenolic compounds. Phenolic compounds are one of the main secondary metabolites of olive leaves. ${ }^{20-23}$ It has also been found that water/aqueous-ethanol/acetone mixtures are generally more effective solvents to extract the polyphenolic compounds of olive leaves. ${ }^{20-23}$

The antioxidant activity of OLEs may directly be related to the polyphenol content. ${ }^{21,23}$ Oleuropein, is the major secondary metabolite and has been extensively studied, but available information is limited for different OLEs. ${ }^{21-23}$ Oleuropein is an important metabolite for the antioxidant ability of OLEs. ${ }^{9}$ For the OLEs, acetone and ethanol extracts exhibit higher antioxidant capacity in both methods (DPPH and ABTS). Our results were consistent with the literature, and acetone and ethanol extracts with high oleuropein content were effective as antioxidant scavengers. ${ }^{23-26}$ In a study using solid-liquid extraction technique and three different extraction solvents 
[petroleum ether, water, methanol (80\%)], suggested that flavonoids (from 3.33-17.64 mg catechin equivalents/g), phenolics (from 3.64-21.47 mg GAE/g) were abundant in the content of OLEs, and their analysis correlated with antioxidant capacity. ${ }^{24}$ These data are consistent with our results presented in this study.

OLEs caused cytotoxicity in many different cancer cells such as human breast cancer cells (MCF7) and colorectal cancer cells (HT29). ${ }^{25,26}$ Kimura and Sumiyoshi ${ }^{27}$ investigated the effects of OLE and oleuropein on the skin cancer animal model. According to their investigations, oleuropein and OLE were superior to the control group in skin thickness and tumor incidence. Barbaro et al. ${ }^{28}$ suggested that olive leaves and oleuropein antitumor activity may be related with ROS scavenging effect, antiproliferative effect, apoptosis induction, angiogenesis inhibition, and antimigration effect. Our study is coherent with the previous studies, and we found that OLEs at different concentrations inhibits H4IIE cancer cells more
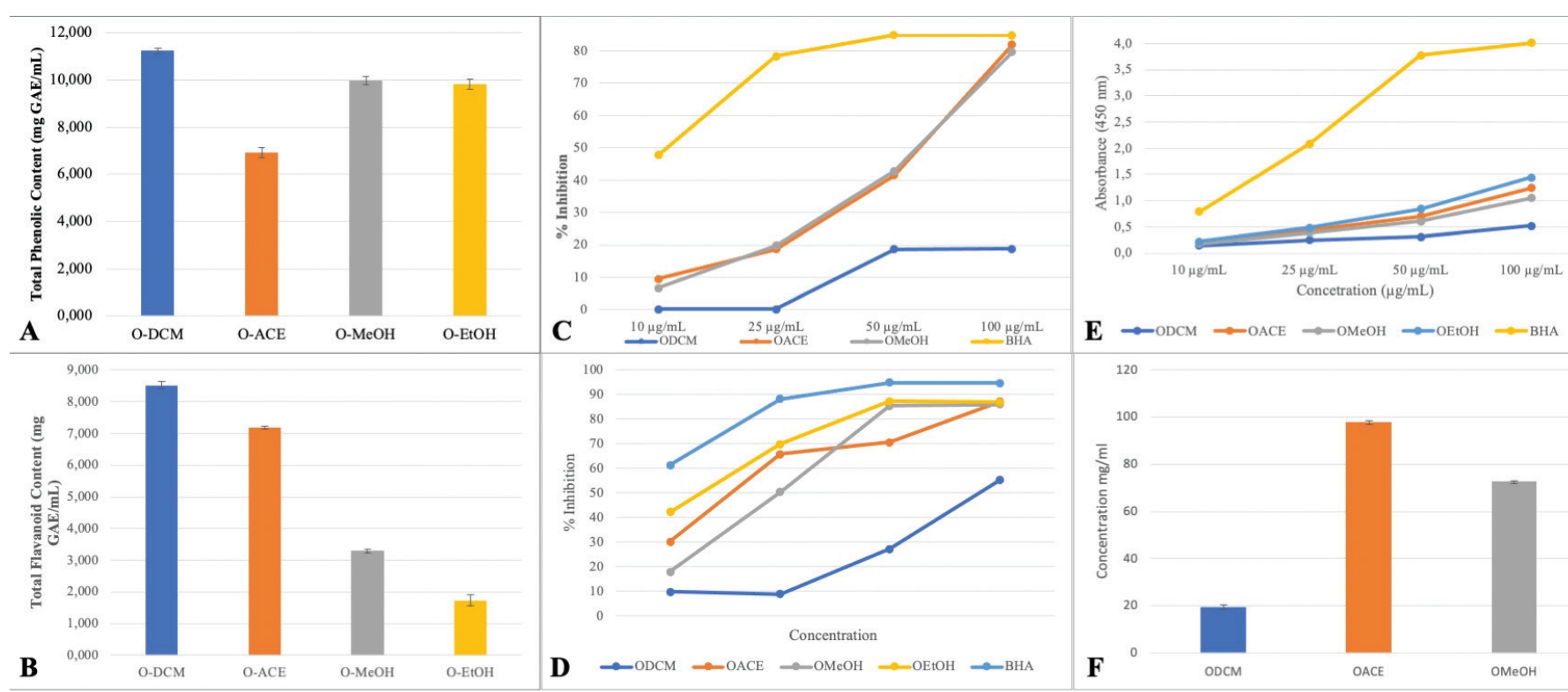

G

Oleuropein Calibration Curve
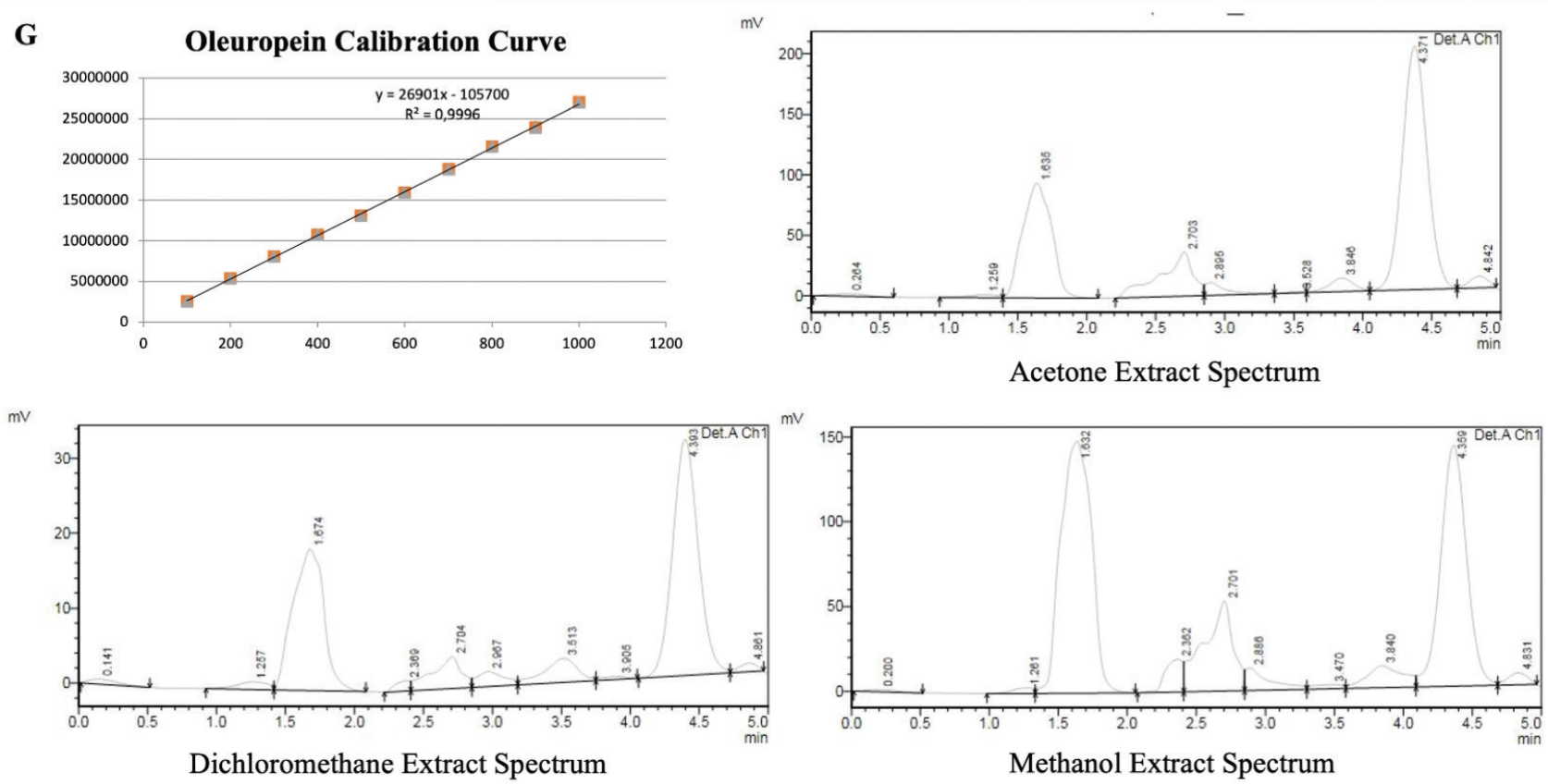

Figure 1. Evaluation of the flavonoid and phenol content, free radical activity, ABTS cation radical scavenging activity, reduction force, and oleuropein level in Olea leaf extracts. (A) Total phenolic compounds of extracts; (B) total flavonoid compounds of extracts; (C) free radical activity of extracts for different concentrations; (D) ABTS cation radical scavenging activity of extracts for different concentrations; (E) reduction force of extracts; (F) oleuropein concentration in extracts. (G) Oleuropein calibration curve and extract spectrums of acetone, dichloromethane, and methanol. GAE: Gallic acid, QUE: Quercetin, O-DCM: OLE with dichloromethane, O-ACE: OLE with acetone, O-MeOH: OLE with methanol, O-EtOH: OLE with ethanol, BHA: Butylated hydroxy anisole 

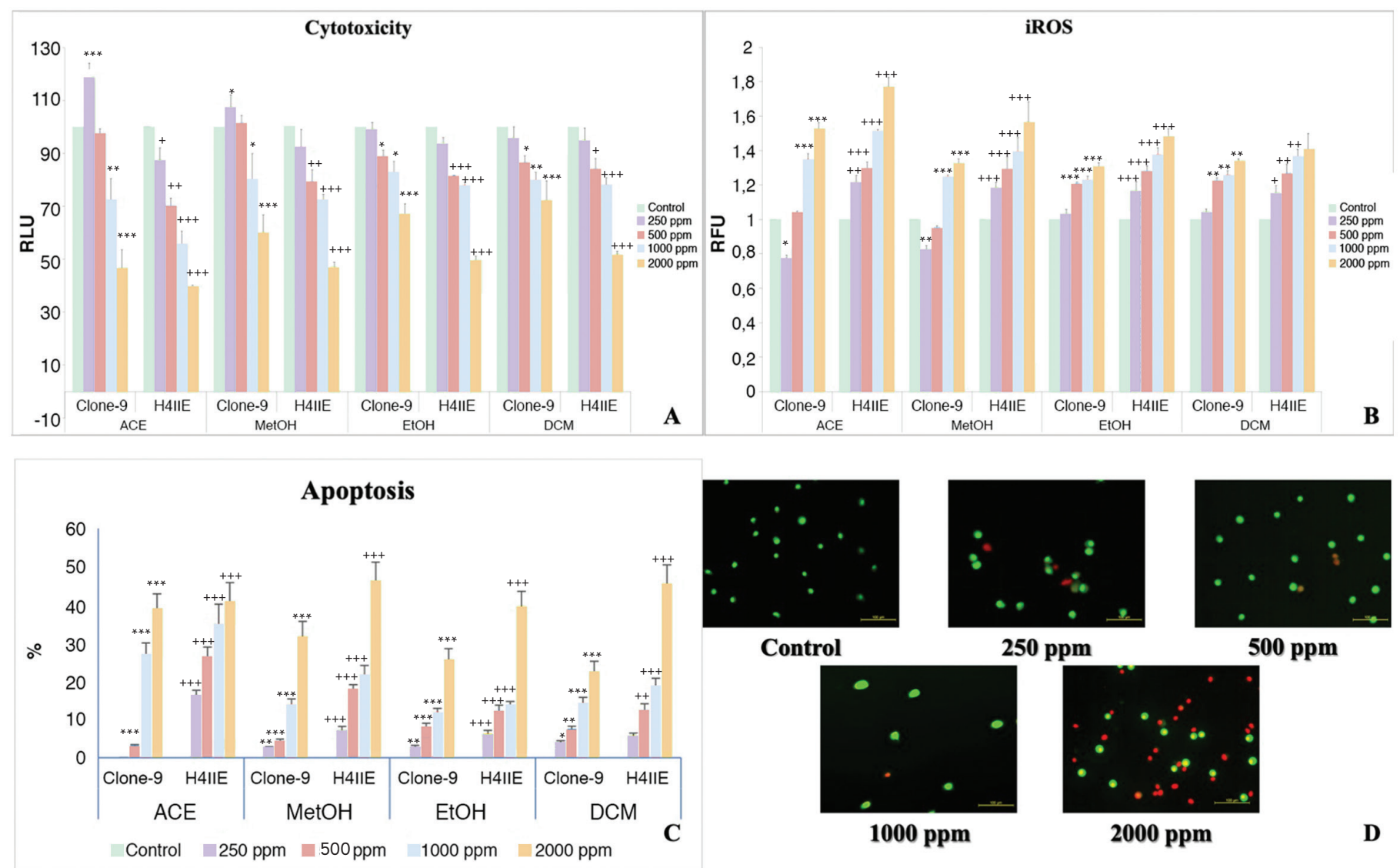

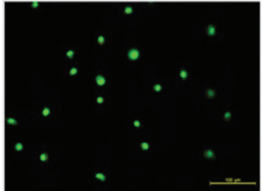

Control

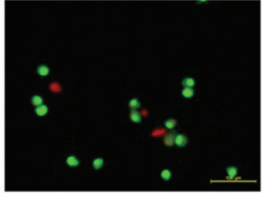

250 ppm

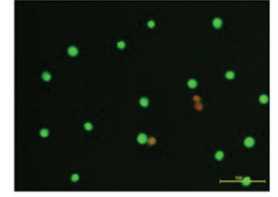

500 ppm

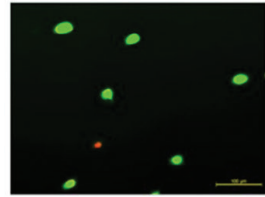

1000 ppm

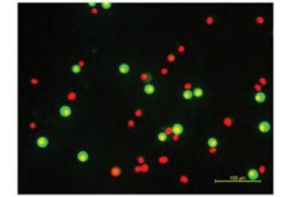

2000 ppm

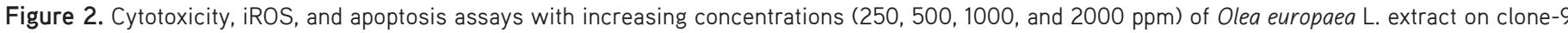

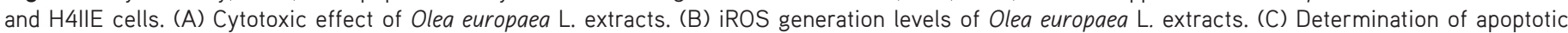

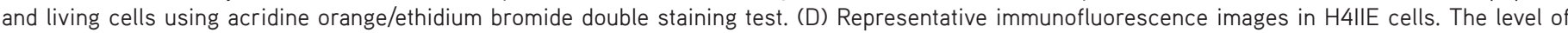

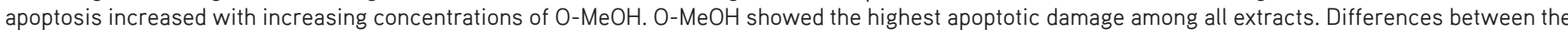

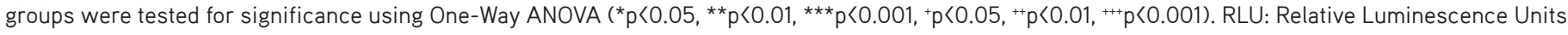

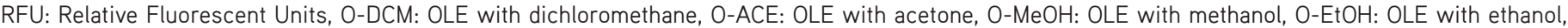
iROS: Intracellular reactive oxygen species

than clone-9 healthy cells (Figure 2). In fact, at $0.25 \mathrm{mg} / \mathrm{mL}$ concentrations, acetone and methanolic extracts positively affected cell viability in terms of Relative Luminescence Units in the healthy clone- 9 cell line. This indicates that OLE causes selective cytotoxicity in rat hepatoma cell lines, but not in healthy hepatocytes. This selectivity could be a result of the susceptibility of cancer cells to intracellular ROS formation. Cancer cells have increased ROS producing capacity, and therefore the selective activity of OLE on H4IIE may be due to their increased susceptibility to the iROS. The effects of OLE on H4IIE cells may offer opportunities for new chemoprevention studies for liver cancer.

On the other hand, the higher concentration of OLE was induced cytotoxicity and iROS for both healthy and cancer cell lines. These results indicate that the dose of the extracts have a crucial role in the pharmacological effect. According to concentration, OLE may induce or inhibit cytotoxicity and apoptosis. According to Park et al. ${ }^{29}$ mice fed with an oleuropein-supplemented diet attenuated hepatic steatosis in microscopic and macroscopic scale. According to the literature and our results, OLE or oleuropein-supplemented diet has protective effects on liver diseases.

In literature, via various mechanisms, olive leaves may induce apoptosis and inhibit cell proliferation. Oleuropein stops cell growth and promotes the apoptosis in HT29 colorectal cancer cells via a p53-dependent pathway. ${ }^{25,26}$ This apoptotic effect with a similar mechanism was also reported in breast cancer cells. ${ }^{30}$ In addition, on doxorubicin-induced cardiomyopathy, oleuropein, major phenolic of olive leave showed a protective effect through AMPK activation and iNOS suppression. ${ }^{27}$ This study revealed that OLE, which contains oleuropein as major secondary metabolites has antitumor activity in the hepatoma cell lines. These results are partly consistent with the apoptosis mechanism described in MCF-7 cells treated with oleuropein. ${ }^{30}$ iROS is thought to be related the activation of AKT. ${ }^{31,32}$ Oleuropein may suppress the phosphorylation of AKT. Apoptotic effects of OLE may be related PI3K/AKT pathway, which is a critical pathway for H4llE cells.

Antigenotoxic agents often show expected therapeutic effects that may be effective to control the cancer. Our results were 


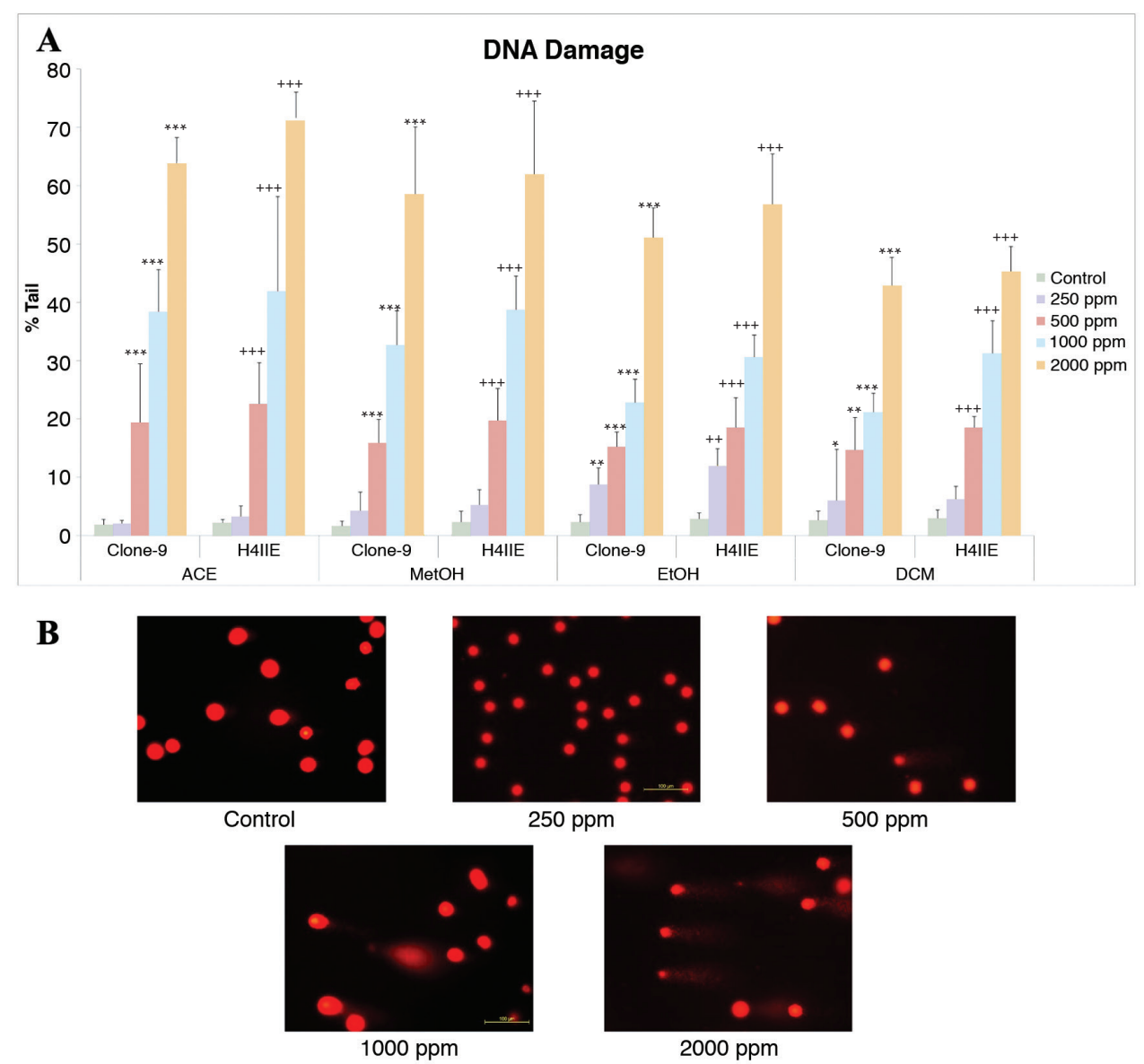

Figure 3. Olive leave extracts cause DNA damage with increasing concentrations (250, 500, 1000, and 2000 ppm) on H4IIE cells. (A) Genotoxic effects of olive leaf extract with increasing concentrations (250,500, 1000, and 2000 ppm) using comet assay after 24-hour incubation. (B) Representative immunofluorescence images in H4IIE cells. The level of DNA damage increased with increasing concentrations of O-ACE. O-ACE showed the highest genotoxic damage among all extracts. Differences between the groups were tested for significance using One-Way ANOVA ( ${ }^{*} p<0.05,{ }^{* *} p<0.01,{ }^{* * *} p<0.001$, $+p<0.05,++p<0.01,+++p<0.001)$. O-DCM: OLE with dichloromethane, O-ACE: OLE with acetone, O-MeOH: OLE with methanol, O-EtOH: OLE with ethanol

promising that OLE reduced cell viability in H4llE cells and were consistent with the literature showing that OLE may inhibit the proliferation of malignant cells in vivo. ${ }^{29-34}$ This feature of OLE may be explained by its capacity to act as a strong free radical scavenger, as shown in Figure 1.

Our results pointed out, OLE have induced the IL-1 $\beta, I L-6$, and $\mathrm{TNF}-\alpha$ production in a concentration-dependent manner. A significant decrease in the proinflammatory cytokine levels was found in cells treated with different OLE. Our results were also consistent with the literature in terms of antiinflammatory effects. ${ }^{9}$ In comparison with the healthy and cancer cell lines, anti-inflammatory effects were significantly higher in healthy cell lines. On the other hand, the increased inflammatory response of cancer cell lines is desirable, which starts apoptosis cascades. The possible anti-inflammatory mechanism may be related with arachidonic acid pathway, mitogen-activated protein kinase (MAPK), and MAPK enzymes such as p38, extracellular signal-related kinase, and $\mathrm{c}$-Jun $\mathrm{N}$ terminal kinase induce transcriptional and posttranscriptional, activation of COX enzymes. Anti-inflammatory effects of $O$. europaea L. may be accomplished through NFKB activation. Inhibition of this proinflammatory cytokines production could be related either with the oleuropein or other secondary metabolites. ${ }^{35}$ Oleuropein is the fundamental OLE component that exhibits anti-inflammatory effects at a concentration of $20 \mu \mathrm{g} / \mathrm{mL} .{ }^{9}$ In another study, OLE reduced mRNA expression of E-selectin in human coronary artery endothelial cells stimulated with serum amyloid-A, as well as decreased IL- 6 and IL- 8 protein levels and reduced matrix metalloproteinase 2 levels in non-stimulated cells. ${ }^{34}$ In both studies, the amount of OLE used was $20 \mu \mathrm{g} / \mathrm{mL}$ and $0.5-1 \mu \mathrm{g} /$ $\mathrm{mL}$, respectively. Compared with our OLE $(0.25-2 \mathrm{mg} / \mathrm{mL})$ concentrations, these results show that high amounts of OLE show pro-oxidant activity.

\section{CONCLUSION}

To the best of our knowledge, this is the first study in the literature investigating the cytotoxic, genotoxic, and apoptotic activity of OLEs on liver cancer cell lines. OLEs activated cytotoxic and apoptotic mechanisms on cancer cells. For this reason, OLEs may have a potential for the cancer treatment. More detailed in vivo studies are needed in the future. 

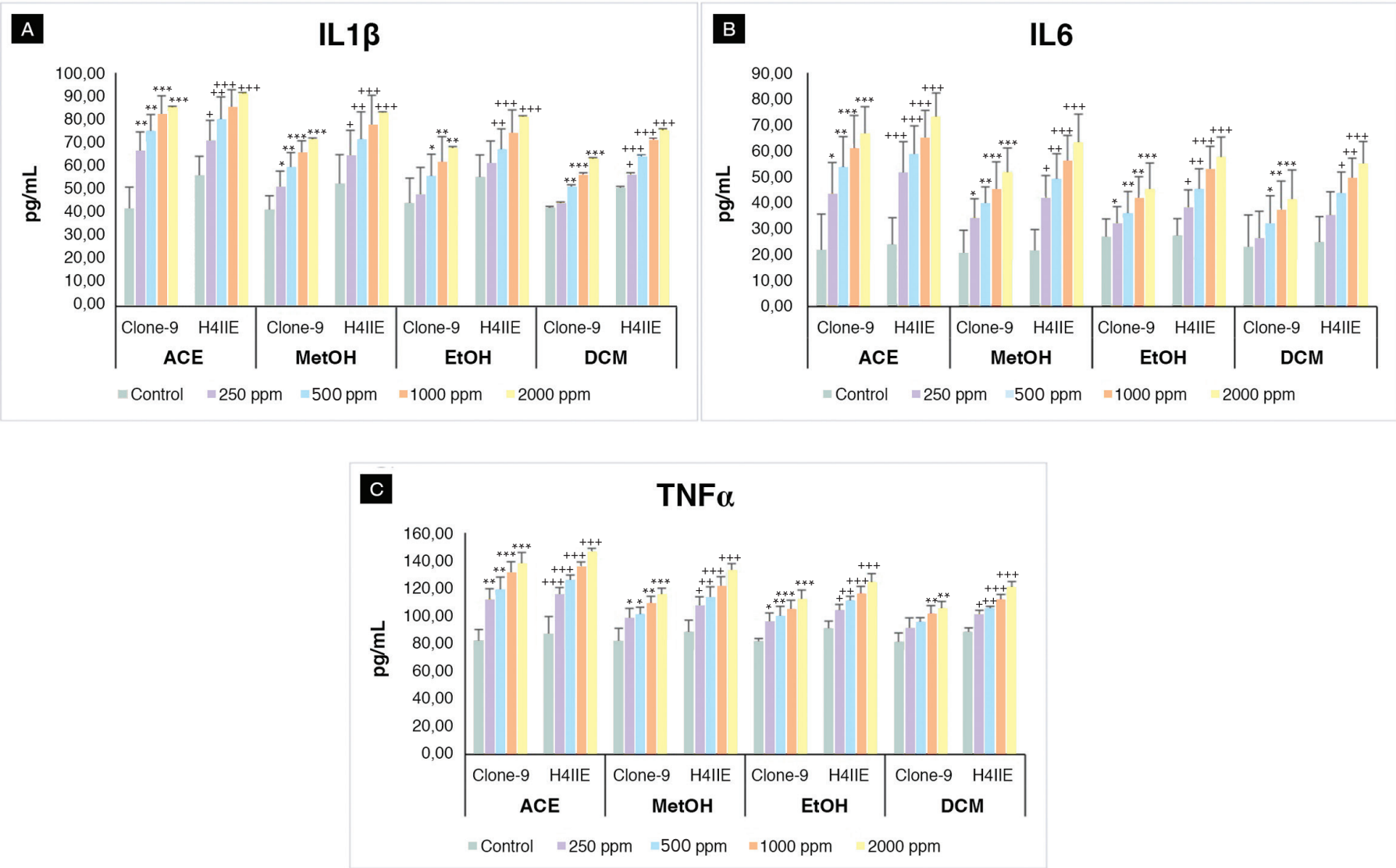

Figure 4. Levels of IL-1 $\beta, I L-6$, and TNF- $\alpha$ with the increasing concentrations (250, 500, 1000, and 2000 ppm) of OLE on clone-9 and H4lIE cells after 24-hour incubation. (A) IL-1 $\beta$ levels (B) IL-6 levels (C) TNF- $\alpha$ levels. Differences between the groups were tested for sign+ificance using One-Way ANOVA $\left({ }^{*} p<0.05,{ }^{* *} p<0.01,{ }^{* * *} p<0.001,{ }^{+} p<0.05,{ }^{++} p<0.01,{ }^{++} p<0.001\right) .0-D C M$ : OLE with dichloromethane, O-ACE: OLE with acetone, O-MeOH: OLE with methanol, O-EtOH: OLE with ethanol, IL: Interleukin

\section{ACKNOWLEDGMENTS}

We are grateful to Hümeyra ŞAHIN-BEKTAY for her valuable contribution during her undergraduate education to our research.

Conflict of interest: No conflict of interest was declared by the authors. The authors are solely responsible for the content and writing of this paper.

Funding sources: This study has been supported by the Scientific Research Unit of Bezmialem Vakif University with a grant number of $9.2015 / 22$.

\section{REFERENCES}

1. Alqahtani A, Khan Z, Alloghbi A, Said Ahmed TS, Ashraf M, Hammouda DM. Hepatocellular carcinoma: molecular mechanisms and targeted therapies. Medicina (Kaunas). 2019;55:526.

2. Rao CV, Newmark HL, Reddy BS. Chemopreventive effect of squalene on colon cancer. Carcinogenesis. 1998;19:287-290

3. Hartke J, Johnson M, Ghabril M. The diagnosis and treatment of hepatocellular carcinoma. Semin Diagn Pathol. 2017;34:153-159.
4. Nabavi SF, Bilotto S, Russo GL, Orhan IE, Habtemariam S, Daglia M, Devi KP, Loizzo MR, Tundis R, Nabavi SM. Omega-3 polyunsaturated fatty acids and cancer: lessons learned from clinical trials. Cancer Metastasis Rev. 2015;34:359-380.

5. Kachhap SK, Dange P, Nath Ghosh S. Effect of omega-6 polyunsaturated fatty acid (linoleic acid) on BRCA1 gene expression in MCF-7 cell line. Cancer Lett. 2000;154:115-120.

6. Boss A, Bishop KS, Marlow G, Barnett MP, Ferguson LR. Evidence to support the anti-cancer effect of olive leaf extract and future directions. Nutrients. 2016;8:513.

7. Hamshoum H, Vlavcheski F, Tsiani E. Anticancer effects of oleuropein. Biofactors. 2017:43:517-528.

8. EI SN, Karakaya S. Olive tree (Olea europaea) leaves: potential beneficial effects on human health. Nutr Rev. 2009;67:632-638.

9. Qabaha K, Al-Rimawi F, Qasem A, Naser SA. Oleuropein is responsible for the major anti-inflammatory effects of olive leaf extract. J Med Food. 2018;21:302-305.

10. Singleton VL, Orthofer R, Lamuela-Raventós R. M. Analysis of total phenols and other oxidation substrates and antioxidants by means of folin-ciocalteu reagent. Methods Enzymol. 1999;299:152-178. 
11. Gülçin I, Berashvili D, Gepdiremen A. Antiradical and antioxidant activity of total anthocyanins from Perilla pankinensis decne. J Ethnopharmacol. 2005;101:287-293.

12. Park Y, Koo M, Ikegaki M, Contado Jl. Comparison of the flavonoid aglycone contents of Apis mellifera propolis from various regions of Brazil. Arq Biol Tecnol. 1997;40:97-106.

13. Blois MS. Antioxidant determinations by the use of a stable free radical. Nature 1958;181:1199-1200.

14. Re R, Pellegrini N, Proteggente A, Pannala A, Yang M, Rice-Evans C. Antioxidant activity applying an improved ABTS radical cation decolorization assay. Free Radic Biol Med. 1999;26:1231-1237.

15. Apak R, Güçlü K, Ozyürek M, Karademir SE. Novel total antioxidant capacity index for dietary polyphenols and vitamins $C$ and $E$, using their cupric ion reducing capability in the presence of neocuproine: CUPRAC method. J Agric Food Chem. 2004;52:7970-7981.

16. Al-Rimawi F. Development and validation of a simple reversed-phase HPLC-UV method for determination of oleuropein in olive leaves. J Food Drug Anal. 2014;22:285-289.

17. Kasibhatla S, Amarante-Mendes GP, Finucane D, Brunner T, BossyWetzel E, Green DR. Acridine Orange/Ethidium Bromide (AO/EB) Staining to Detect Apoptosis. CSH Protoc. 2006;2006:pdb.prot4493.

18. Ribble D, Goldstein NB, Norris DA, Shellman YG. A simple technique for quantifying apoptosis in 96-well plates. BMC Biotechnol. 2005;5:12.

19. Singh NP, McCoy MT, Tice RR, Schneider EL. A simple technique for quantitation of low levels of DNA damage in individual cells. Exp Cell Res. 1988;175:184-191.

20. Putnik P, Francisco BJ, Zoran Z, Dragovic-Uzelac V, Bursac Kovacevic D. Green extraction approach for the recovery of polyphenols from Croatian olive leaves (Olea europea). Food Bioprod. Process. 2017. doi:10.1016/j. fbp.2017.08.004

21. Sudjana AN, D'Orazio C, Ryan V, Rasool N, Ng J, Islam N, Riley TV, Hammer KA. Antimicrobial activity of commercial Olea europaea (olive) leaf extract. Int J Antimicrob Agents. 2009;33:461-463.

22. Altiok E, Bayçin D, Bayraktar O, Ülkü S. Isolation of polyphenols from the extracts of olive leaves (Olea europaea L.) by adsorption on silk fibroin. Sep Purif Technol 2008;62:342-348.

23. Anokwuru CP, Anyasor GN, Ajibaye O, Fakoya O, Okebugwu PO. Effect of extraction solvents on phenolic, flavonoid and antioxidant activities of three nigerian medicinal plants. Nat Sci 2011;7:53-61.

24. Debib A, Boukhatem MN. Phenolic content, antioxidant and antimicrobial activities of "chemlali" olive leaf (Olea europaea L.) extracts. Int J Pharmacol Phytochem Ethnomedicine. 2017;6:38-46.
25. Cárdeno A, Sánchez-Hidalgo M, Rosillo MA, Alarcón de la Lastra C. Oleuropein, a secoiridoid derived from olive tree, inhibits the proliferation of human colorectal cancer cell through downregulation of HIF-1 $\alpha$. Nutr Cancer. 2013;65:147-156.

26. Hassan ZK, Elamin MH, Omer SA, Daghestani MH, Al-Olayan ES, Elobeid MA, Virk P. Oleuropein induces apoptosis via the p53 pathway in breast cancer cells. Asian Pac J Cancer Prev. 2014;14:6739-6742.

27. Kimura $Y$, Sumiyoshi M. Olive leaf extract and its main component oleuropein prevent chronic ultraviolet $\mathrm{B}$ radiation-induced skin damage and carcinogenesis in hairless mice. J Nutr. 2009;139:2079-2086.

28. Barbaro B, Toietta G, Maggio R, Arciello M, Tarocchi M, Galli A, Balsano C. Effects of the olive-derived polyphenol oleuropein on human health. Int J Mol Sci. 2014;15:18508-18524.

29. Park JH, Jung JH, Yang JY, Kim HS. Olive leaf down-regulates the oxidative stress and immune dysregulation in streptozotocin-induced diabetic mice. Nutr Res. 2013;33:942-951.

30. Sirianni R, Chimento A, De Luca A, Casaburi I, Rizza P, Onofrio A, lacopetta D, Puoci F, Andò S, Maggiolini M, Pezzi V. Oleuropein and hydroxytyrosol inhibit MCF-7 breast cancer cell proliferation interfering with ERK1/2 activation. Mol Nutr Food Res. 2010;54:833-840.

31. Liu J, Zhou J, Xing D. Phosphatidylinositol 3-kinase plays a vital role in regulation of rice seed vigor via altering NADPH oxidase activity. PLoS One. 2012;7:e33817.

32. Abaza L, Talorete TP, Yamada P, Kurita Y, Zarrouk M, Isoda H. Induction of growth inhibition and differentiation of human leukemia HL-60 cells by a Tunisian gerboui olive leaf extract. Biosci Biotechnol Biochem. 2007;71:1306-1312.

33. Topalović DŽ, Živković L, Čabarkapa A, Djelić N, Bajić V, Dekanski D, Spremo-Potparević B. Dry olive leaf extract counteracts L-thyroxineinduced genotoxicity in human peripheral blood leukocytes in vitro. Oxid Med Cell Longev. 2015;2015:762192.

34. Burja B, Kuret T, Janko T, Topalović D, Živković L, Mrak-Poljšak K, Spremo-Potparević B, Žigon P, Distler O, Čučnik S, Sodin-Semrl S, Lakota K, Frank-Bertoncelj M. Olive leaf extract attenuates Inflammatory Activation and DNA damage in human arterial endothelial cells. Front Cardiovasc Med. 2019;6:56

35. Santangelo C, Vari R, Scazzocchio B, De Sanctis P, Giovannini C, D'Archivio M, Masella R. Anti-inflammatory activity of extra virgin olive oil polyphenols: which role in the prevention and treatment of Immunemediated Inflammatory diseases? Endocr Metab Immune Disord Drug Targets. 2018;18:36-50. 